\title{
DESAIN VISUAL DAN KOMUNIKASI BISNIS DALAM PERENCANAAN EVENT PELUNCURAN BUKU MANTAPPU JIWA
}

\author{
Mercy Lona Darwaty Ryndang Sriganda ${ }^{1)}$, Prin Suprianto ${ }^{2)}$, \\ Rofi Saeful Rohman ${ }^{3)}$ \\ Universitas Indraprasta PGRI
}

\begin{abstract}
Abstrak. Buku Latihan Soal Mantappu Jiwa merupakan sebuah buku autobiografi yang ditulis oleh seorang content creator YouTube bernama Jerome Polin Sijabat yang khusus mengangkat konten edukasi dan informasi tentang matematika, budaya, dan kehidupannya selama menjalani pendidikan di Jepang. Peluncuran buku tersebut dikemas dalam sebuah event yang diadakan di salah satu Mall di Jakarta Selatan pada tanggal 16 Agustus 2019. Event peluncuran buku merupakan salah satu kegiatan promosi guna membangun awereness terhadap audience. Sebelum diadakan sebuah event peluncuran buku terdapat tahapan yang dilakukan yakni pembuatan iklan melalui media digital yang menggunakan desain visual. Tahapan tersebut merupakan bagian dari rangkaian perencanaan event peluncuran buku. Tujuan penulisan untuk memberikan gambaran mengenai perencanaan event peluncuran buku dan event peluncuran Buku Latihan Soal Matappu Jiwa sebagai subjek analisisnya. Selain itu, dengan gambaran tersebut dapat lebih memahami bentuk desain visual dan komunikasi bisnis yang ada dalam sebuah acara peluncuran buku. Dalam penulisan artikel ini menggunakan metode kualitatif dengan sumber data sekunder yang diperoleh dari berbagai sumber literatur, jurnal artikel ilmiah, dan kiriman yang terdapat di website dan akun media sosial dari penulis dan penerbit yaitu PT Gramedia Pustaka. Dari data yang diperoleh bahwa sebelum mengadakan event peluncuran buku dilakukan perencanaan berupa komunikasi melalui media digital sebagai pengambil keputusan diadakannya event tersebut.
\end{abstract}

Kata kunci: Desain Visual, Komunikasi Bisnis, Perencanaan Event, Peluncuran Buku

\begin{abstract}
The Exercise Practice Book Mantappu Jiwa is an autobiographical book written by a YouTube content creator named Jerome Polin Sijabat who specifically addresses educational content and information about mathematics, culture, and life while undergoing education in Japan. The book launch was packaged in an event held in one of the Mall in South Jakarta on August 16, 2019. The book launching event was one of the promotional activities to build awareness of the audience. Before a book launching event was held, there were steps to do, namely the creation of advertisements through digital media that uses visual design. The stages are part of a series of book launch event planning. The purpose of writing is to provide an overview of the planning of the book launch event and the event launching of the Mantappu Jiwa Matter Exercise Book as the subject of its analysis. In addition, with this description can better understand the forms of visual design and business communication that exist in a book launch event. In writing this article using qualitative methods with secondary data sources obtained from various literary sources, scientific article journals, and submissions contained on the website and social media accounts of authors and publishers namely PT Gramedia Pustaka. From the data obtained that before holding a book launch event, planning is carried out in the form of communication through digital media as the decision maker for the event.
\end{abstract}

Keywords: Visual Design, Business Communication, Event Planning, Launching Book.

Correspondence Author: Mercy Lona Daraty Rynang Sriganda, mercy.lona@unindra.ac.id, Jakarta, Indonesia 


\section{Pendahuluan}

Buku Mantappu Jiwa adalah sebuah buku autobiografi tentang Jerome Polin Sijabat. Buku ini ditulis sendiri oleh Jerome untuk membagikan kisah perjalanannya dalam menempuh pendidikannya di Jepang. Jerome merupakan seorang content creator YouTube dengan nama akun "Nihongo Mantappu" yang sekarang sudah memiliki lebih dari 2,26 juta subscriber. Selain menceritakan kisah hidupnya, dalam buku tersebut penulis membagikan kiat-kiat dan ilmu matematika yang dia peroleh selama pendidikannya.

Dalam peluncuran buku Mantappu Jiwa, event sebagai media promosi. Efektivitas dari kegiatan promosi sangat tergantung oleh relevansi kegiatan tersebut terhadap sasaran yang diinginkan oleh individu, perusahaan maupun organisasi. Ada empat variabel atau jenis promosi yaitu periklanan (adversiting), penjualan perseorangan (personal selling), publisitas (publicity), promosi penjualan (sales promotion) yang semakin dikenal dalam dunia bisnis dan pemasaran (Syamsu). Promosi merupakan bagian penting dalam sebuah event, agar promosi dapat berjalan baik maka sebelum melakukan promosi baik organisasi maupun individu tentu memiliki perencanaan yang tepat untuk mendapatkan hasil yang maksimal (Wulandari).

Dalam dalam rangkaian acara peluncuran buku Buku Latihan Soal Mantappu Jiwa merupakan sebuah promosi di bidang pemasaran baik promosi buku itu sendiri maupun yang penulis, mengingat penulis dari buku tersebut merupakan seorang YouTuber yang cukup sukses. Komunikasi yang digunakan dalam peluncuran buku ini tentu saja disesuaikan dengan konsep dan juga audience yang hadir dalam acara peluncuran buku tersebut. Hal ini pasti menjadi perhatian utama untuk event organizer karena untuk mempersiapkan dan hal-hal yang berkaitan dengan konsumen tentu harus didasari oleh pendekatan secara benar agar terjalin sebuah komunikasi yang intens dan tidak memberatkan audience.

Dalam peluncuran buku Mantappu Jiwa terdapat event yang merupakan bagian dari kegiatan pemasaran. Pemasaran itu sendiri adalah sebuah rancangan penyampaian alur produk ke pembeli. Pada perancangannya terdapat inovasi dan disiplin dari sang perancang pemasaran. Pemasar harus memiliki ide yang kreatif untuk memunculkan konsep sebagai pemasaran. Di mana konsep tersebut harus mampu memberi keuntungan secara finansial dan keuntungan sosial berupa hubungan baik antara penjual dan pembeli menurut (Blythe, Jim; Megicks, P. dalam Rukmana and Komariah).

Komunikasi adalah suatu proses pertukaran informasi antar individu melalui suatu sistem yang biasa (lazim), baik dengan simbol-simbol, sinyal-sinyal, maupun perilaku atau tindakan. Pada umumnya, pengertian komunikasi paling tidak melibatkan dua orang atau lebih, dan proses pemindahan pesan dapat dilakukan dengan menggunakan cara-cara berkomunikasi yang bisa dilakukan oleh seseorang melalui lisan, tulisan, maupun sinyal-sinyal nonverbal (Silintowe and Pramudita).

Salah satu media komunikasi adalah buku. Buku merupakan sebuah produk hasil karya manusia berupa ilmu, pengetahuan, budaya dan sebuah tanda peradaban. Buku juga merupakan produk bisnis yang terus berputar dari tahun ke tahun. Buku memiliki segmentasi dari semua kalangan masyarakat, mulai dari anak-anak, remaja, dewasa dan juga lansia. Kian melebarnya bisnis ini, menjadikan sebagian orang untuk mengkomunikasikan pemasaran buku dengan acara peluncuran buku sebagai alat atau media untuk memasarkan produk buku sehingga lebih menarik perhatian konsumen.

Berdasarkan hal tersebut dapat disimpulkan bahwa sebuah event atau acara peluncuran buku merupakan suatu jenis komunikasi dalam berbisnis dengan buku sebagai dipromosikan dalam acara tersebut. Peluncuran buku sebagai media dalam mempromosikan buku baru 
tentunya harus memiliki market atau pasar yang jelas dengan di dasari oleh ilmu tertentu dibidang pemasaran.

Menurut Roger Bennett, "marketing managers require marketing knowledge to inform decision-making and for the subsequent implementation of decisions" yang berarti bahwa setiap manajer pemasaran harus mempersiapkan pengetahuan pemasaran untuk menginformasikan dan mengambil keputusan di tiap implementasi program pemasaran (Rukmana and Komariah).

Dalam hal ini kondisi pasar yang dimaksud adalah peluncuran buku. Peluncuran buku harus didasari oleh pengetahuan komunikasi dan pengelolaan acara untuk memudahkan pengaplikasian konsep pemasaran dalam meningkatkan penjualan buku. Salah satu aspek yang perlu diperhatikan dalam konsep komunikasi adalah cara berkomunikasi dengan melalui analisis konsumen. Komunikasi harus sesuai dengan konsumen berupa, gaya bicara, umur, status sosial, pendidikan dari konsumen atau yang menghadiri acara peluncuran buku tersebut. Komunikan dan pengelola acara harus memahami pola komunikasi dari konsumen sehingga dapat terjadi komunikasi yang terarah, dapat di terima dan juga mudah dimengerti oleh konsumen.

Event memiliki arti sebagai suatu kegiatan yang diadakan untuk merayakan atau memperingati hal-hal yang penting sepanjang hidup manusia, baik itu secara individu atau kelompok yang memiliki keterikatan secara adat, budaya, tradisi, maupun agama yang penyelenggaraannya memiliki tujuan tertentu dan melibatkan lingkungan masyarakat dalam waktu tertentu (Suhartanto and Noor). Rhenald Kasali menjelaskan bahwa event organizer adalah sebuah bisnis yang di dalamnya menerapkan konsep manajemen secara berkesinambungan serta konsisten dalam mengeksplorasi dunia entertainment sedalamdalamnya. Dibalik kegiatan tersebut terdapat tim yang mencatat setiap detail dari proses memilih acara, mengemas acara, memenuhi pembayaran, mengurus perizinan, meyakinkan keamanan pelaksanaan, merekam gejolak keinginan pasar serta menyiapkan teknologi dan cara pemasarannya, hingga evaluasi (event report).

Penulisan ini bertujuan untuk memberikan gambaran mengenai perencanaan event peluncuran buku dan event peluncuran Buku Latihan Soal Matappu Jiwa sebagai subjek analasisnya. Selain itu, dengan gambaran tersebut dapat lebih memahami bentuk deain visual dan komunikasi bisnis yang saling menunjang dalam sebuah acara peluncuran buku.

\section{Metode}

Penulisan artikel ini menggunakan metode kualitatif dengan data sekunder sebagai rujukannya. Data sekunder diperoleh dari buku, jurnal dan artikel. Menurut Bogdan dan Taylor (1975) mengemukakan bahwa metodelogi kualitatif merupakan sebuah prosedur penelitian yang berupa kata-kata atau tulisan dari buku atau orang yang diamati. Metode ini dipilih untuk memperoleh data informasi untuk dianalisis dan digunakan pula untuk penyusunan penelitian dengan studi pustaka (Habsy) .

Sumber data berupa data sekunder yaitu studi pustaka. Studi pustaka dilakukan untuk memperoleh bahan atau data berupa literatur tertulis, buku, dan jurnal ilmiah yang berhubungan dengan objek kajian. Hal ini dilakukan untuk mendapat kajian berupa dokumen cara-cara melakukan atau merealisasikan sebuah rancangan dalam peluncuran buku. Studi pustaka dilakukan secara online dan offline. Maksud dari studi pustaka secara online yaitu pengambilan data berupa e-book atau buku elektronik dan juga jurnal ilmiah yang ada di internet. Adapun studi pustaka secara offline yaitu berupa pengambilan data secara offline dengan mengunjungi perpustakaan yang menyediakan buku-buku yang berkaitan dengan objek 
kanjian. Analisis pengambilan data yang disajikan berupa gabungan-gabungan dari beberapa sumber artikel, buku dan jurnal ilmiah berhubungan dengan komunikasi, manajemen, iklan, marketing, penyelenggaraan peluncuran buku yang disusun secara sedemikian rupa menjadi runtut dan urut.

\section{Hasil dan Pembahasan}

Event peluncuran buku Latihan Soal Mantappu Jiwa merupakan bagian dari serangkaian kegiatan pemasaran atau promosi. Kegiatan ini bertujuan untuk membangun awareness khalayak terhadap buku Mantappu Jiwa. Hal ini sejalan dengan fungsi event yang memiliki arti penting sebagai media yang efektif dalam membangun good will publik pada sebuah produk yang ingin dipasarkan. Sebuah acara event peluncuran buku merupakan sebuah inovasi dari segi cara mempromosikan sebuah buku yang akan terbit. Hal ini bertujuan untuk meningkatkan nilai profit atau penjualan dari buku tersebut. Memang dalam kenyataannya tidak semua buku yang terbit dibuatkan acara peluncuran buku oleh penerbit. Hanya buku-buku yang memiliki peluang untuk mendapatkan keuntungan yang besar yang dibuatkan acara peluncuran buku oleh penerbit. Hal paling penting dari sebuah acara peluncuran buku adalah publikasi kepada masyarakat. Dalam acara peluncuran buku biasanya diikuti dengan acara bedah buku dan jumpa penggemar. Penulis yang hadir selain mempromosikan bukunya juga untuk menyapa penggemarnya. Sedangkan bedah buku sendiri digunakan untuk memperdalam makna makna yang tersirat dalam buku sebagai sebuah komunikasi antar penulis dengan penggemarnya. Hal ini disebabkan karena biaya yang diperlukan untuk membuat acara peluncuran buku cukup besar sehingga banyak penerbit ataupun penulis buku yang menerbitkan bukunya melalui media digital seperti media sosial. Media sosial dinilai lebih efektif untuk menekan biaya promosi karena biayanya cenderung lebih murah.

Buku Latihan Soal Mantappu Jiwa merupakan buku yang memiliki segmentasi untuk remaja. Sang penulis, Jerome Polin Sijabat memiliki tujuan agar melalui bukunya dapat meningkatkan budaya literasi khususnya bagi remaja yang ada di Indonesia. Selain itu melalui bukunya sang penulis berharap para pembaca dapat terinspirasi dari kisah perjalanan hidupnya dalam menggapai cita-citanya seperti yang ia tuangkan dalam bukunya tersebut. Selain kisah hidupnya dalam buku Latihan Soal Mantappu Jiwa tersebut berisi kalimat-kalimat motivasi yang dapat memotivasi pembaca dan beberapa latihan soal matematika, guna memberikan edukasi kepada pembaca buku tersebut oleh karena itu buku tersebut diberi judul Buku Latihan Soal Matappu Jiwa.

Dalam perencanaan acara peluncuran buku terdapat rangkaian kegiatan pemasaran yang mendahului pelaksanaan event tersebut. Sebagai penulis buku Latihan Soal Mantappu Jiwa, Jerome melakukan promosi melalui media sosial yaitu Twitter sebagai langkah awal perencanaan peluncuran bukunya tersebut. Media sosial Twitter dinilai sangat efektif sebagai media promosi karena dapat mencakup khalayak yang luas dan menggunakan biaya yang lebih murah. Dalam aplikasi Twitter tersebut Jerome selaku penulis membuat polling, yang mana data dari polling tersebut dapat berguna bagi penentuan langkah selanjutnya dalam rangkaian perencanaan peluncuran bukunya. Selain dari polling, data juga diperoleh dari jumlah komentar yang ada pada kolom komentar setiap unggahannya mengenai peluncuran buku tersebut sehingga dapat disimpulkan seberapa banyak antusiasme khalayak terhadap buku yang akan diluncurkan tersebut. Berikut adalah screen chapture unggahan Jerome Polin dalam akun media sosial Twitter pribadinya terkait dengan perencanaan peluncuran bukunya. 


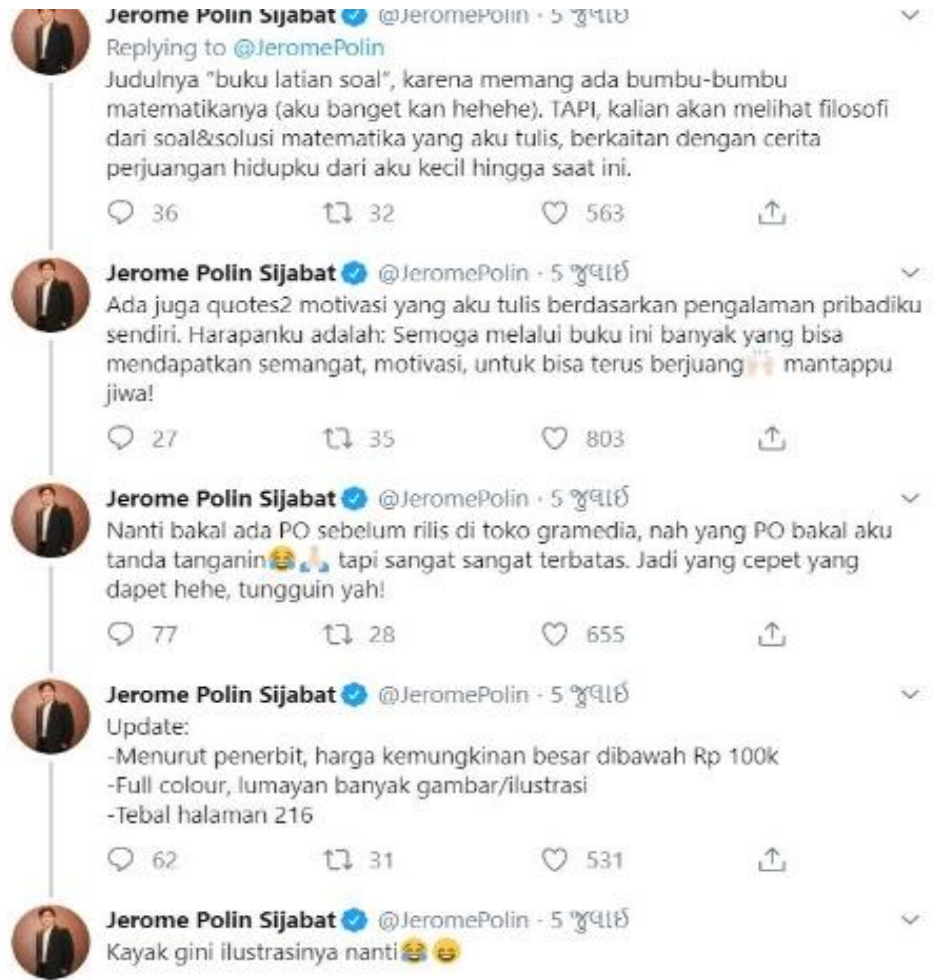

Gambar 1 penyampaian pesan bisnis sebagai bentuk promosi di media sosial (Sumber: twitter.com/@JeromePolin)

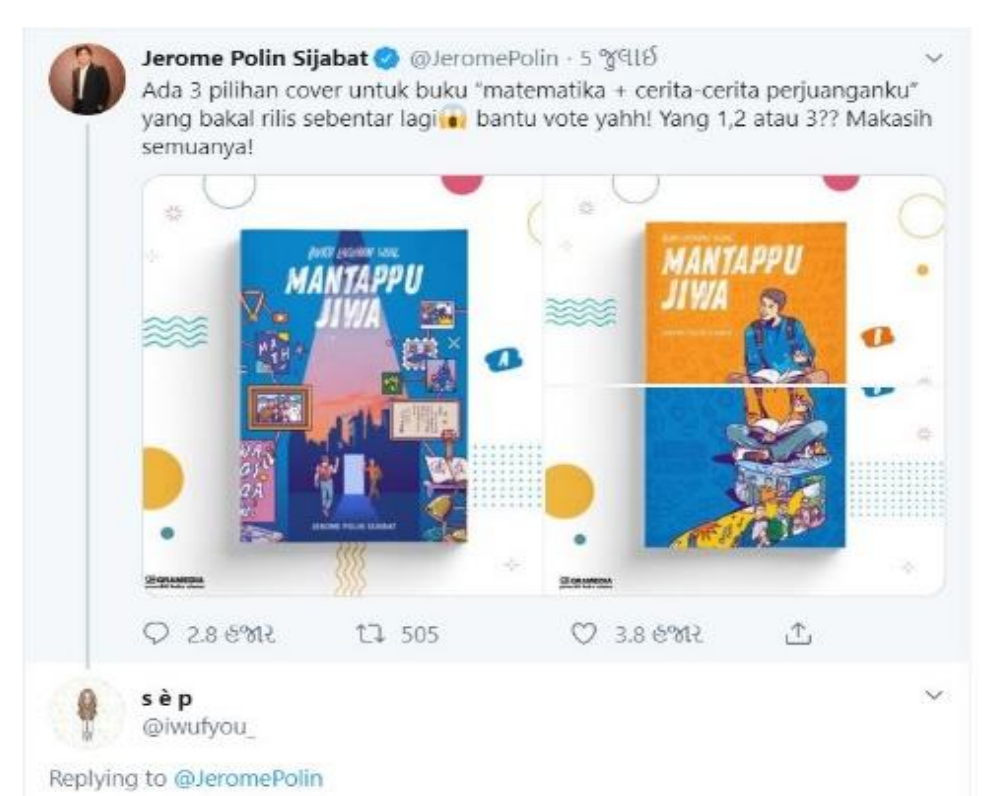

Aku mau bantu

द्वीटणु अनुवाध करो

\begin{tabular}{lr} 
Cover 1 & $83 \%$ \\
\hline Cover 2 & $8 \%$ \\
\hline
\end{tabular}

Gambar 2 Contoh polling yang sebagai dalam media sosial Twitter (Sumber: twitter.com/@JeromePolin) 

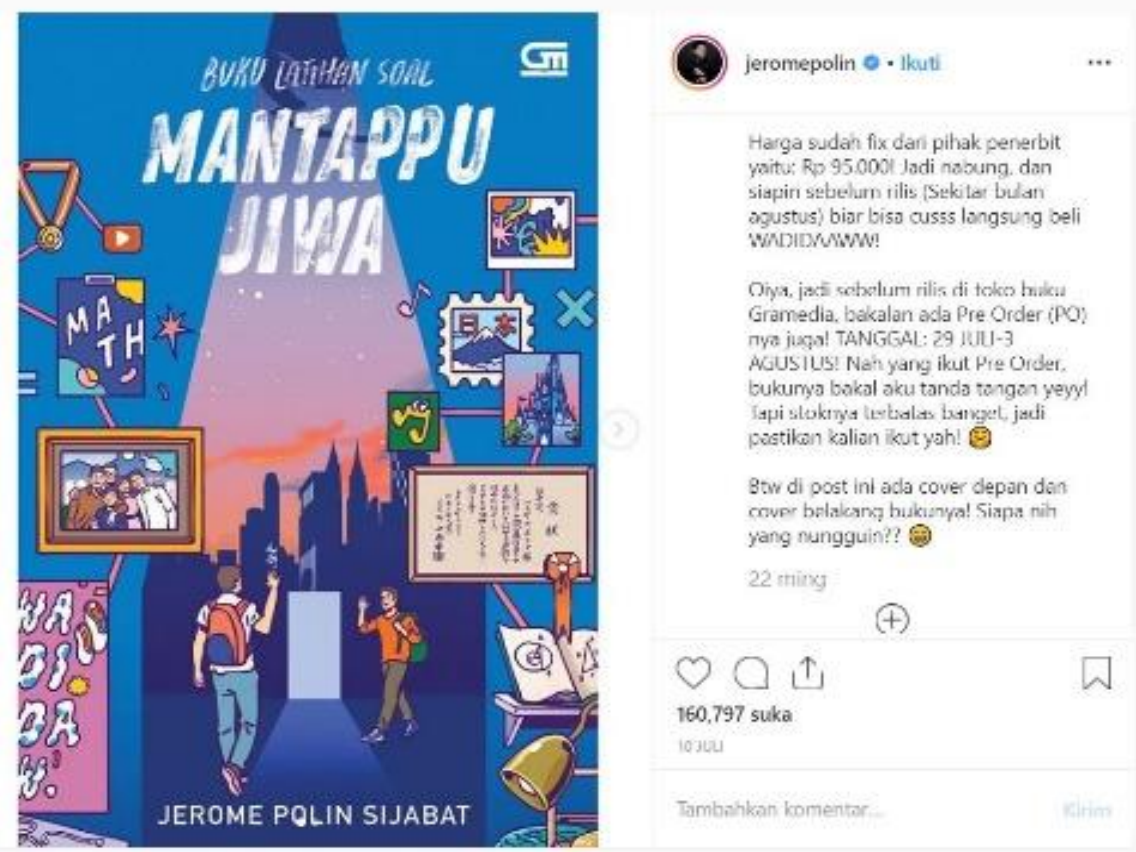

Gambar 3 Bentuk komunikasi bisnis berupa iklan dimedia sosial Instagram

(Sumber: https://www.instagram.com/jeromepolin/)

Penggunaan media sosial sebagai media penyampaian iklan tersebut dalam komunikasi bisnis merupakan bagian dari penyampaian pesan bisnis secara tertulis. Dengan adanya batasan jumlah karakter pada aplikasi media sosial Twitter tersebut mengharuskan pengguna untuk menyampaikan pesannya secara singkat. Pesan yang disampaikan hanya terkait dengan topik dan ide pokok dari pesan yang ingin disampaikan sehingga khalayak lebih mudah untuk menangkap dan memahami pesan yang ingin disampaikan. Penggunaan gaya bahasa yang informal dipilih karena target audience dari buku Latihan Soal Mantappu Jiwa ini adalah anak muda. Penggunaan gaya bahasa informal ini bertujuan menarik khalayak dan mempermudah khalayak menangkap isi pesan yang ingin disampaikan.

Selain dari pihak penulis, promosi juga dilakukan oleh pihak penerbit yaitu PT Gramedia Pustaka. Hal ini dilakukan untuk menjangkau khalayak yang lebih banyak lagi karena promosi yang dilakukan oleh penulis sendiri hanya menjangkau audience yang merupakan penggemar dari penulis tersebut. PT Gramedia Pustaka Utama bekerja sama dengan Tokopedia dalam melakukan pemasaran produk melalui internet dan media sosial. Iklan tersebut bertujuan untuk memberikan informasi kepada khalayak tentang waktu pre-order buku tersebut yang dapat di pesan di laman atau aplikasi Tokopedia secara eksklusif pada tanggal 22-31 Juli. Berikut adalah iklan yang digunakan PT Gramedia Pustaka Utama: 


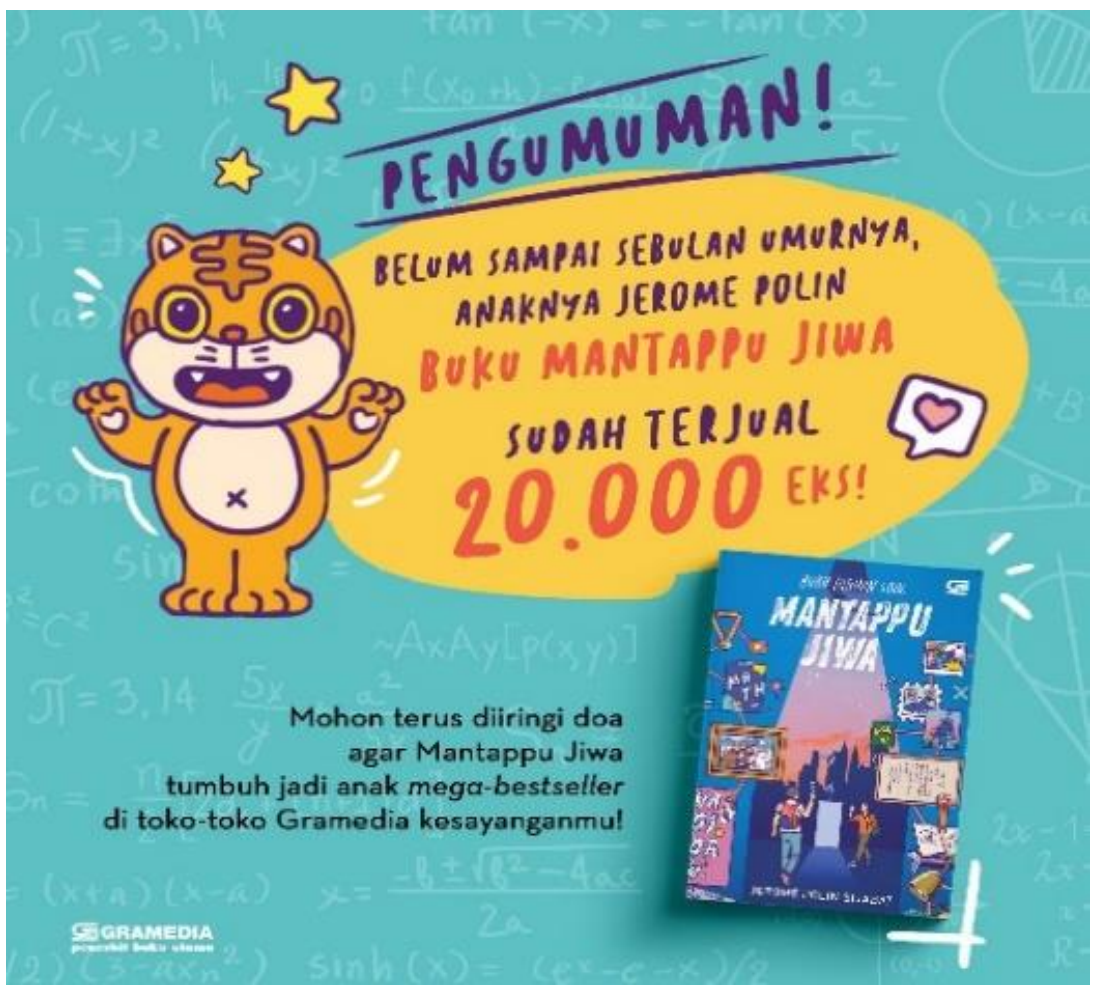

Gambar 4 Iklan di media sosial

(Sumber: twitter.com/@bukugpu)

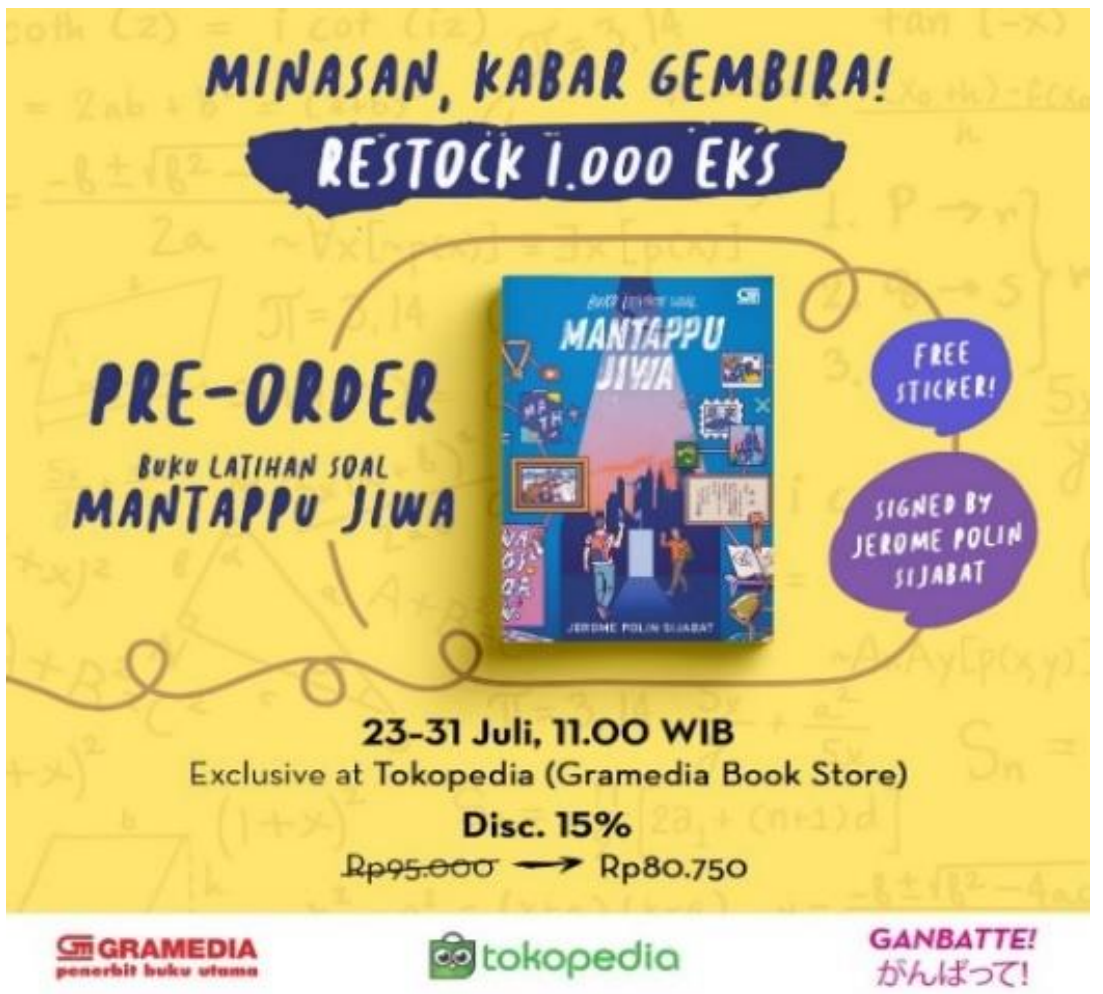

Gambar 5 Iklan di media sosial

(Sumber: twitter.com/@bukugpu) 


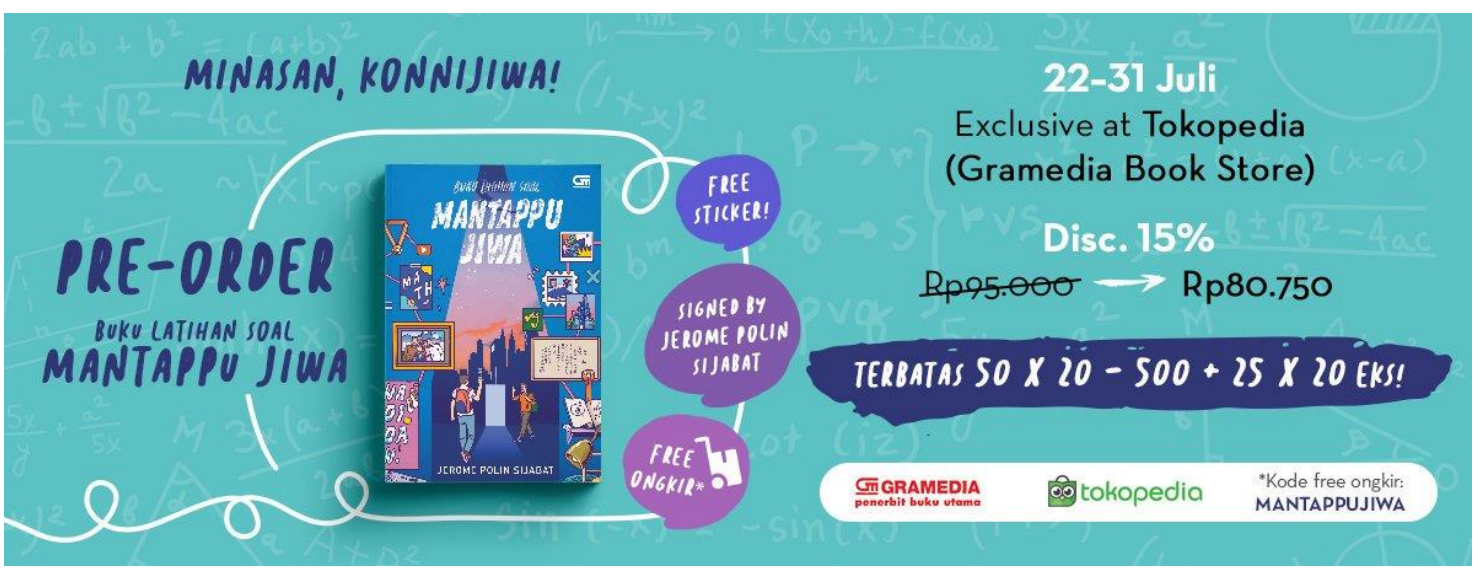

Gambar 6 Iklan di website Gramedia Pustaka

(Sumber: www.gramedia.com)

Iklan tersebut merupakan bagian dari penyampaian pesan bisnis secara tertulis dalam ilmu komunikasi bisnis. Dalam penyampaian pesan tersebut tidak hanya mengandalkan pesan tulisan tetapi juga mengandalkan unsur visual guna menarik perhatian khalayak. Dari segi bahasa dan tulisan dari pesan bisnis tersebut menggunakan gaya bahasa iklan pada umumnya yaitu singkat dan terpusat pada ide pokok dan topiknya. Penggunaan kalimat persuasif berupa pemberian diskon menjadi salah satu cara untuk menarik perhatian khalayak untuk memesan buku Latihan Soal Mantappu Jiwa tersebut. Dari segi visual iklan tersebut menggunakan gaya desain minimalis dan menyerupai tulisan di papan tulis yang menggambarkan tema dari isi buku Mantappu Jiwa yang merepresentasikan cerita hidup penulis yang berkutat dengan pendidikan dan sekolah di dalam buku tersebut. Pemilihan gaya ilustrasi pada iklan tersebut disesuaikan dengan target khalayak yang ingin di cakup oleh PT Gramedia Pustaka Utama selaku komunikan. Penggunaan warna yang terang dan ceria berfungsi untuk menarik perhatian khalayak. Dalam teori psikologi warna, warna dapat mempengaruhi emosi seseorang. Penggunaan warna dapat menciptakan daya tarik terhadap manusia untuk tertarik atau bergairah pada suatu hal. Warna berguna sebagai alat komunikasi nonverbal yang bisa menyampaikan pesan secara tersirat dengan instan dan mudah diserap maknanya. Penggunaan warna tosca pada iklan tersebut selain melambangkan kecerdasan dari penulisnya juga dapat mempengaruhi emosi khalayak di mana warna tosca membawa kesan ketenangan. Sedangkan warna kuning identik dengan kebahagiaan dan keceriaan yang dapat mempengaruhi khalayak untuk melihat iklan tersebut tersebut sehingga khalayak membaca isi pesan pada secara detail.

\section{Event Peluncuran Buku}

Setelah melalui tahapan pertama berupa iklan melalui media digital baik media sosial dan website diketahui bahwa peminat dari buku Latihan Soal Mantappu Jiwa. Dari tahap preorder yang pertama yang dilakukan berjumlah seribu buku langsung habis dalam waktu lima menit kemudian pada pre-order kedua berjumlah seribu buku habis dalam waktu tiga menit. Sehingga dapat disimpulkan bahwa peminat dari buku Latihan Soal Mantappu Jiwa ini tingggi. Selain itu daftar dari jumlah komentar dan polling yang dilakukan oleh penulis yang berkaitan dengan buku tersebut menguatkan kesimpulan tersebut. Dengan tingginya minat pada buku tersebut penerbit mengadakan event peluncuran buku Mantappu Jiwa pada tanggal 16 Agustus 2019 di Mall FX Sudirman, Jakarta Selatan. Tujuan dalam event peluncuran buku tersebut adalah membangun awareness responden terhadap buku Latihan Soal Mantappu Jiwa. Awareness yang diperoleh dari event peluncuran buku ini tidak hanya diperoleh dari individu saja melainkan dari 
berbagai media-media cetak dan televisi. Selain dari media konvensional tersebut peran individu dalam membagikan momen saat acara peluncuran buku Mantappu Jiwa di media sosial pribadi menjadi salah satu keuntungan dalam membangun awareness tersebut sehingga dapat mencakup khalayak lebih luas.

Dalam event peluncuran buku tersebut ada beberapa hal pendukung agar acara tersebut dapat berjalan dan menarik khalayak untuk datang ke acara tersebut. Pertama adalah penulis sebagai fokus utama. Kehadiran penulis dalam acara peluncuran buku menjadi fokus utama dalam membangun awareness karena dalam acara tersebut terdapat kesempatan bagi para fans untuk bertemu dan berkomunikasi secara langsung dengan idolanya. Kedua adalah pembawa acara yang bertugas mengatur jalannya acara peluncuran buku tersebut. Selain itu pembawa acara juga memiliki peran sebagai perantara komunikasi penulis (bintang tamu) sebagai komunikan dengan audience. Pembawa acara juga memiliki peran penting dalam membangun suasana sehingga acara peluncuran buku tersebut berjalan dengan baik, tidak monoton dan seru sehingga audience menjadi tertarik. Dalam penyampaiannya pembawa acara menggunakan gaya bahasa yang formal dan informal karena target audience dari buku Latihan Soal Mantappu Jiwa ini adalah remaja. Dan terakhir adalah penggunaan backdrop dan $x$-banner sebagai elemen pendukung dan penanda acara peluncuran buku tersebut. Dengan adanya backdrop dan $x$-banner ini dapat menarik khalayak yang ada di lokasi event tersebut. Gaya desain dan ilustrasi yang digunakan dalam backdrop dan $x$-banner masih sama seperti pada iklan-iklan yang digunakan di media digital dan media sosial. Berikut adalah foto dari acara event peluncuran buku Latihan Soal Matapu Jiwa:

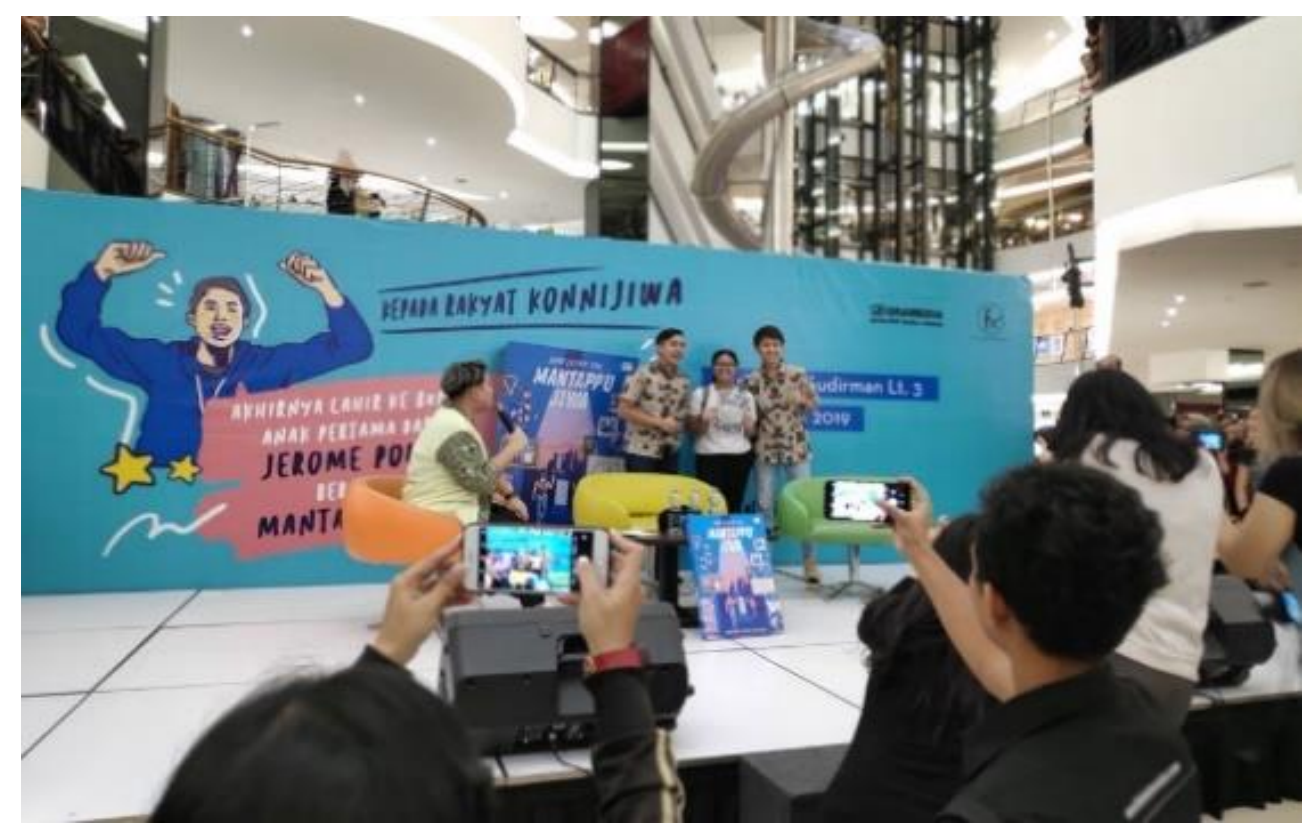

Gambar 7 Event peluncuran buku di FX Sudirman, Jakarta Selatan

(Sumber: https://www.gramedia.com/blog/mantappu-jiwa/\#gref) 


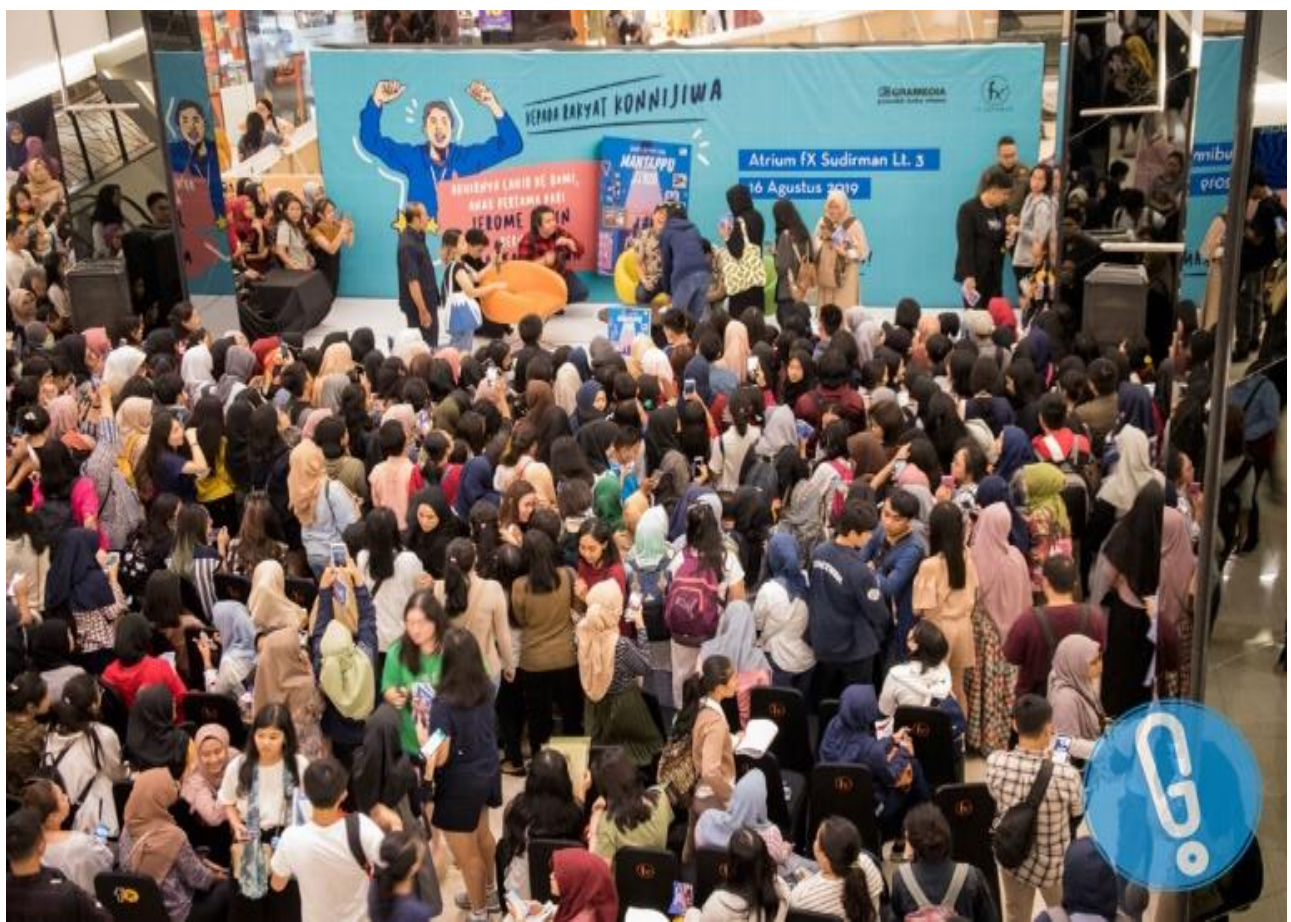

Gambar 8 Event peluncuran buku di FX Sudirman, Jakarta Selatan (Sumber: https://www.gramedia.com/blog/mantappu-jiwa/\#gref)

\section{Simpulan}

Kegiatan event peluncuran buku merupakan salah satu bentuk promosi Buku Latihan Soal Mantappu Jiwa yang dalam perencanaannya terdapat tahapan-tahapan yang mendahului sebelum diputuskan untuk diselenggarakan. Tidak semua buku yang terbit diadakan event peluncuran buku oleh penerbit. Hal ini dikarenakan penerbit memiliki dana yang terbatas dan penerbit tidak hanya menerbitkan satu atau dua buku setiap bulannya. Sehingga hanya bukubuku yang memiliki kemungkinan mendapat keuntungan yang besar atau mempunyai peminat yang banyak yang diadakan event peluncuran buku.

Kolaborasi desain viasual dan komunikasi bisinis dilakukan Jerome Polin selaku penulis dan PT Gramedia Pustaka sebagai penerbit dengan mengiklankan melalui media digital baik media sosial maupun website. Hal ini bertujuan untuk mengetahui antusiasme audiens terhadap buku yang akan diterbitkan tersebut. Dengan banyaknya antusiasme audiens terhadap buku tersebut maka dipustuskan event peluncuran buku tersebut diadakan. Hal ini guna membangun awareness dengan cakupan yang lebih luas terbukti dengan banyaknya audiens yang turut menghadiri event peluncuran buku Latihan Mantappu Jiwa. Dengan diadakannya event tersebut mampu menaikkan penjualan Buku Latihan Mantappu Jiwa itu sendiri hingga terjual sebanyak 20.000 eksemplar dalam kurun waktu kurang dari satu bulan semenjak acara peluncuran tersebut diadakan dan menjadikan buku tersebut best seller di beberapa outlet Gramedia hingga bulan November 2019. 


\section{Daftar Pustaka}

Habsy, Bakhrudin All. "Seni Memehami Penelitian Kuliatatif Dalam Bimbingan Dan Konseling: Studi Literatur." Jurnal Konseling Andi Matappa, vol. 1, no. 2, 2017, pp. 90-100.

Rukmana, Evi Nursanti and Neneng Komariah. "Strategi Pemasaran Informasi Toko Buku (Studi Kasus Di Toko Buku Jatinangor, Sumedang)." Berkala Ilmu Perpustakaan dan Informasi, vol. 13, no. 2, 2017, pp. 131-141, doi:https://doi.org/10.22146/bip.28764.

Silintowe, Yunita Budi Rahayu and Margareta Cahya Christy Pramudita. "Komunikasi Bisnis Lintas Budaya Sekretaris Pada Atasan (Studi Pada Alila Hotel Solo)." Jurnal Komunikasi, vol. 8, no. 2, 2017, pp. 147-158, doi:http://dx.doi.org/10.24912/jk.v8i2.67.

Suhartanto, Dwi and Any Noor. "Attitudinal Loyalty in the Budget Hotel in-Dutry: What Are the Important Factors?" Journal of Tourism, Hospitality \& Culinary Arts, vol. 5, no. 2, 2013, pp. 64-74.

Syamsu, Aria Kusuma. "Peranan Bauran Promosi Terhadap Peningkatan Volume Penjualan (Studi Kasus Pada Dealer Sepeda Motor Honda Pt Nusantara Surya Sakti Bululawang)." Jurnal Administrasi Bisnis, vol. 16, no. 1, 2014, pp. 1-8, http://administrasibisnis.studentjournal.ub.ac.id/index.php/jab/article/view/658.

Wulandari, Lusi Setyo. "Penyelenggaraan Bedah Buku Sebagai Sarana Promosi Perpustakaan Bank Indonesia Semarang." Jurnal IImu Perpustakaan, vol. 4, no. 3, 2015, pp. 141-150, https://ejournal3.undip.ac.id/index.php/iip/article/view/9734. 